\title{
Does Participatory Planning Foster the Transformation Toward More Adaptive Social-Ecological Systems?
}

\author{
Susanne Menzel $^{l}$ and Matthias Buchecker ${ }^{l}$
}

\begin{abstract}
The need for social-ecological systems to become more adaptive is widely acknowledged. Social effects generated by participatory planning have been claimed to contribute to this transformation, but little empirical evidence is available that backs up or opposes this notion. We aimed to offer some insights regarding questions as to which social effects are formed in participatory planning processes and at what costs, and to then discuss their contribution to the transformation toward more adaptive social-ecological systems based on empirical evidence. Consequently, we investigated the social effects of participatory planning processes, including the social learning processes leading to them. We conducted semistructured interviews with members of advisory groups involved in river engineering projects in Switzerland. Our results indicate that participatory planning processes can somewhat contribute to maintaining and spreading knowledge and social capital among individuals in a planning group, and this may help them collectively deal with new and complex challenges. However, it is costly in terms of time and patience to build up ecological knowledge, communicative capacities, and trust, with the latter also eroding over time. Overall, we conclude that the contribution of participatory planning via positive social outcomes to the transformation toward adaptive capacity social-ecological systems is smaller than optimists might hope. However, other forms of planning very likely result in no social effects or even the destruction of social capital. Participatory planning, in contrast, can offer the conditions for relational and cognitive learning contributing to the maintenance of social and political capital. Based on our results, we suggest shifting resources from technical to communicative aspects of planning processes and implementations. We recommend that project leaders provide stakeholders with firsthand information about projects, explain rationales and data behind decisions, and clearly communicate that stakeholders do not have decision making competence to support participants in finding their roles in similar participatory planning settings.
\end{abstract}

Key Words: comanagement; participatory planning; planning costs; qualitative research; social capital; social learning; time requirements

\section{INTRODUCTION}

The need for social-ecological systems to become more adaptive is recognized by many practitioners and researchers. Recently, participatory planning and comanagement were discussed as a key element of this transforming process (PahlWostl et al. 2007). Processes of participatory planning, used synonymously with comanagement throughout this study, are expected to bring about social learning through social interaction. Social learning is both cognitive and value-related and can, for example, create social as well as political capital. Learning and its effects not only help to solve particular management problems but are also expected to make communities more responsive, resilient, and capable (Kuhlicke et al. 2011). However, we suspect that unrealistically high hopes for the impact of participatory planning on social-ecological transformations may be held. We ground this suspicion on excessive expectations of outcomes of participatory approaches held in the past, such as resistance-free acceptance of projects. Subsequently, there were setbacks when expectations were not met (see, for e.g., Dorcey and McDaniels 2001). We thus argue that we should abandon overly ambitious goals, develop realistic expectations, and improve knowledge about the requirements for achieving sustainability aims. Realistic expectations of learning effects and subsequent social outcomes of participatory planning reduce the risk of major failure with a subsequent possible reversion to autocratic or pseudodemocratic decision making styles.

Thus arose the main question of this study, to investigate which of the predicted social effects already described in the literature (Innes and Booher 1999) were in fact generated in actual participatory planning processes. We have a particular interest in social learning and its contribution to long-term effects of the participatory planning process. There are two subsidiary questions. First, we wanted to examine what types of learning occurred and who was learning what. Second, we wanted to reveal what process conditions contributed to the creation of social effects and what costs, including time investments, had to be assumed to realize participatory processes and associated positive social effects. Finally, we try to answer the higher level question, what are realistic expectations regarding the contribution of participatory planning to the transformation toward more adaptive social-ecological systems?

Early work on social effects of collaborative planning and their contribution to managing complex adaptive systems was conducted in the late 1990s. Innes and Booher (1999) presented a comprehensive but nonempirical account that 
identified first-, second-, and third-order social effects of collaborative planning. These authors argued that participatory initiatives first produced social learning that in turn resulted in social and other forms of capital. Then, after the implementation of agreements, changes in perceptions and practices occurred and social effects spread beyond particular projects. Innes and Booher further suggested that midterm new collaborations were initiated as a result of earlier collaborative efforts, fewer destructive conflicts emerged, and new institutions were launched in the longer run. This seminal work suggested that collaboration produced solely positive social outcomes in managing complex adaptive systems. More recent work on social and relational effects of participatory planning in the context of management under uncertainty focused on social learning (Mostert et al. 2008), capacity building (Kuhlicke et al. 2011), and capital formation (Pahl-Wostl et al. 2007).

There is also a trend to investigate more specific social outcomes of collaborative processes, such as social capital (Wagner and Fernandez-Gimenez 2009). Related studies have shown, for example, that trust building effects and other positive psychosocial effects could emerge as outcomes of participatory planning processes (Leach et al. 2002, Höppner et al. 2007), and that social capital was built in participatory planning processes under certain conditions, e.g., when initial trust levels were high (Wagner and Fernandez-Gimenez 2009). Only a couple of studies focused particularly on time requirements for social effects to emerge. One of these studies showed that social capital, as well as new collaborative initiatives, only accrued and emerged after approximately four years of collaborative engagement as the result of previous participatory efforts (Leach et al. 2002).

Critics indicated that social capital might be consumed as a result of collaborative efforts and warned that the participation of stakeholders could lead to an aggravation of conflicts (Leach et al. 2002, Bullock and Hanna 2007). Some authors claimed that "consensus among stakeholders is often not achieved, and processes are often conflict-ridden, inefficient, and/or unsatisfactorily settled." (Sheppard and Meitner 2005:173). Other authors did not stress the negative effects of collaborative efforts, but noted the limitations of such efforts and the challenges to produce social outcomes, and, particularly, social learning (Muro and Jeffrey 2008, PahlWostl 2009). In an effort to make favorable outcomes more likely than unwanted ones, reviews have been conducted that identified general best practices in participatory planning, which pointed to the relevance of the quality of participatory processes to produce favorable results (e.g., Reed 2008) and that attempt to link process conditions and context features to outcomes (Newig and Fritsch 2009). Studies have also tried to identify conditions that hinder and foster social learning and associated social effects, pointing to opportunities for interaction, including clarity of the process, its openness and transparency, or access to adequate resources (Mostert et al. 2007). Munro and Jeffrey (2012) have shown that the conditions or how participatory processes are organized, for example, time frame of participation, group size, or prevailing mode of communication, could significantly affect the learning outcomes. Whereas cognitive changes also happened under less favorable process conditions, relational changes seemed to depend on more intensive participation. Still, little is known about the range of social outcomes that occur, particularly whether the expected long-term effects occur. Even less is known about the dynamics of different forms of social learning and the costs of developing social effects.

In the context of research on adaptation and transformation toward more adaptive social-ecological systems, comanagement and participatory planning are in vogue despite the calls for caution resulting from earlier research (Dorcey and McDaniels 2001). Recently a debate emerged on the contribution of participatory planning to adaptation (Stringer et al. 2006) and the transformation toward adaptive social-ecological systems (Rauschmayer et al. 2009) building on contributions of comanagement to resilience (Olsson et al. 2004). Empirical research has been conducted on social effects in this context, for example, under the label of monitoring the governance dimension of comanagement (Cundill and Fabricius 2010). Social learning effects of participatory methods are also being investigated in this new context (Garmendia and Stagl 2010). This research, however, pays little attention to social effects from a long-term perspective, which would seem to be particularly relevant to the discussion about social-ecological transformations. Garmendia and Stagl (2010), for example, compared the effects of only two to three workshops in three case studies and merely considered the workshops' short-term social learning effects; this examination allowed few conclusions regarding participatory processes' potential to contribute to forming adaptive social-ecological systems. This limitation was further endorsed by Garmendia and Stagl who found that the time given to a process influenced whether there was "a significant increase in the understanding of other participants' perception after workshop participation." (Garmendia and Stagl 2010:1717). As in earlier research, smaller than expected relational and social learning effects of collaborative decision making and planning were noted, as well as the need for long-term facilitation and secure and continuous financing of participatory planning (Cundill and Fabricius 2010).

Also, in the context of evaluating comanagement projects, the social learning concept has gained increasing recognition but has also been criticized for its lack of conceptual clarity (Armitage et al. 2008, Muro and Jeffrey 2008, and see also Reed 2010, as cited in Rodela et al. 2012). We followed a pragmatic approach with regard to the conceptual underpinning as laid out in the next section. 
With our investigation, we attempted to shed more light on three issues: first, on the contribution of participatory planning processes to the creation of a broad range of social effects; second, on the ways and forms social learning occurred; third, on the costs and conditions of these processes. This will enable a discussion of the contribution of participatory planning to social-ecological transformations as a result of effects occurred, their extension beyond the directly involved individuals in the participatory planning processes, and the detected extent of social learning.

\section{CONCEPTUAL FRAMEWORK, SETTING, AND METHODS}

\section{Conceptual framework}

The conceptual framework for our empirical study drew on the works of Muro and Jeffrey $(2008,2012)$ and Innes and Booher (1999). Muro and Jeffrey illustrated an idealized 'compound model of social learning' based on a literature review (Muro and Jeffrey 2008) that they recently updated (Muro and Jeffrey 2012). In its latest form, the model depicts planning process features that fosters social learning, e.g., open communication. The model also conceptualizes social learning as contributing to collective action via common understanding. Social learning also contributes to the acquisition of factual knowledge, communication skills, trust, and relationships. Collective action or changes in the physical environment, we called substantial effects, and changes in peoples' minds, whether of cognitive or relational nature, we called social effects. Muro and Jeffrey assumed these two kinds of outcomes were independent.

Innes and Booher (1999) implicitly conceptualized the relationship between social effects and substantial effects differently and represented the latter as results of the former in a more linear model. Innes and Booher also considered longterm social effects, such as new institutions and change in norms and practices, which followed implementations; these authors called those effects third-order effects. Leach and Sabatier proposed a two-way relationship between social capital and agreements in which social capital fosters agreements and agreements, in turn, nurture and promote social capital (Leach and Sabatier 2005); thus, these authors saw a positive feedback loop between social and substantial effects.

Our conceptual model, with which we tried to accommodate earlier research, took elements from all three models. We explicitly assumed that social and substantial effects existed and that their creation was interdependent, whereas social conditions and learning were preconditions for implementations. We also assumed that implementations fostered or maintained the stock of social and political capital.

We were aware of the conceptual fuzziness (Arnold et al. 2012) in the realm of research that touched upon social learning, social capital, political capital, and the like. For example, trust had been conceptualized as a subcategory of social capital in the past, but Muro and Jeffrey (2012) recently considered it as a subdimension of social learning. We sensed that we would not significantly contribute to the conceptual debate based on a single empirical study and assumed that readers with different conceptual understandings would be able to integrate our findings in their mental models. To facilitate the integration of our findings in earlier research, we give brief definitions of the key concepts.

Social capital is understood here as built by individuals who are embedded in a group, that entails relationships of trust, that individuals in a group follow norms of reciprocity, and that networks exist among said individuals. (Bourdieu 1986, Coleman 1988, Wagner and Fernandez-Gimenez 2008). This conception entails that social capital can be used to acquire other forms of capital. Political capital was seldom defined in the academic literature, and if it was, it was understood to be "the resources used by an actor to influence policy formation processes and realize outcomes that served the actor's perceived interests" (Birner and Wittmer 2003:298). We defined political capital as an individual belonging to a group having the capacity to follow (i.e., conversational) rules that enable the group to act collectively, in its shared interests. As per Muro and Jeffrey (2012), one might call these communication skills.

We defined social learning as relational and cognitive changes that happened as a result of experiences in group settings. Thus, we distinguished social learning from individual learning. For further details of possible definitions and the application of learning theories in environmental management and planning see Armitage et al. (2008). Following Munro and Jeffrey (2012), we distinguished relational changes, that is, how individuals related to other actors in a planning setting, and cognitive changes, which was the acquisition of factual knowledge about the planning situation as forms of social learning. Relying on Armitage et al. (2008), Pahl-Wostl et al. (2007), and earlier work they cited, we distinguished singlefrom double-loop learning and referred to different depth of learning as extent of learning. We defined single-loop learning as the acceptance of new ways of dealing with an issue instead of more fundamental changes in mental models. Double-loop learning, in contrast, "occurred when existing worldviews and underlying values were challenged." (Armitage et al. 2008:88).

\section{Setting}

Our empirical study examined the social effects of combined flood control and restoration projects in Switzerland. In this country, from the late 19th to the late 20th centuries, streams were canalized to gain land and reduce flooding risks to farmland, buildings, and infrastructure (Hostmann and Knutti 2009). As a consequence, $50 \%$ of rivers under 600 meters 
Table 1. Characteristic information of the cases studied.

\begin{tabular}{|c|c|c|c|c|c|}
\hline $\begin{array}{l}\text { Case } \\
\text { (case \# as first digit in } \\
\text { Table 2) } \\
\text { Dimension }\end{array}$ & $\begin{array}{c}\text { Flaz } \\
(5)\end{array}$ & $\begin{array}{l}\text { Kander } \\
(4)\end{array}$ & $\begin{array}{l}\text { Langete } \\
\text { (2) }\end{array}$ & $\begin{array}{l}\text { Thur } \\
\text { (3) }\end{array}$ & $\begin{array}{l}\text { Wyna } \\
\text { (1) }\end{array}$ \\
\hline Canton & Grisons & Bern & Bern & Thurgau & Aargau \\
\hline $\begin{array}{l}\text { Responsible gov. } \\
\text { entity for river } \\
\text { engineering }\end{array}$ & Municipality & Municipality & $\begin{array}{l}\text { Association of } \\
\text { municipalities }\end{array}$ & Canton & Canton \\
\hline $\begin{array}{l}\text { Intensity of } \\
\text { participation (as } \\
\text { number of meetings } \\
\text { and duration of } \\
\text { stakeholder } \\
\text { involvement) } \\
\text { [estimation] }\end{array}$ & Middle & Low & High & High & High \\
\hline Year of trigger & 1987 & 1995 & 1975 & 1987 & 1995 \\
\hline Kind of trigger & $\begin{array}{l}\text { Series of flood event, } \\
\text { and rejection of } \\
\text { permission (by } \\
\text { canton) to further } \\
\text { construct in a real } \\
\text { estate area b/c of } \\
\text { flood risk }\end{array}$ & $\begin{array}{l}\text { Decline of permission by } \\
\text { canton to reconstruct the } \\
\text { damaged flood prevention } \\
\text { construction }\end{array}$ & $\begin{array}{l}\text { Severe flood event and } \\
\text { announcement by } \\
\text { insurance company to not } \\
\text { cover future damages }\end{array}$ & $\begin{array}{l}\text { Series of flood events and } \\
\text { decline of permission for } \\
\text { the implementation of an } \\
\text { existing plan by } \\
\text { federation }\end{array}$ & Series of flood events \\
\hline $\begin{array}{l}\text { Construction (starting } \\
\text { year) }\end{array}$ & 2000 & $\begin{array}{l}2004 \\
\left(1^{\text {st }} \operatorname{leg}\right)\end{array}$ & $\begin{array}{c}1987 \\
\left(1^{\text {st }} \operatorname{leg}\right)\end{array}$ & $\begin{array}{c}1998 \\
\left(1^{\text {st }} \operatorname{leg}\right)\end{array}$ & 2006 \\
\hline $\begin{array}{l}\text { Completion of } \\
\text { construction }\end{array}$ & 2004 & 2005 & 1995 & 2000 & 2008 \\
\hline $\begin{array}{l}\text { \# of years from trigger } \\
\text { to first construction }\end{array}$ & 13 & 10 & 13 & 11 & 11 \\
\hline $\begin{array}{l}\text { River engineering } \\
\text { measures }\end{array}$ & $\begin{array}{l}4000 \mathrm{~m} \text { (river } \\
\text { relocation) }\end{array}$ & $1300 \mathrm{~m}$ (widening) & 15 legs on a $15 \mathrm{~km}$ stretch & $\begin{array}{c}\text { A number of widening } \\
\text { measures on a stretch of } 7 \\
\text { km }\end{array}$ & $\begin{array}{l}2 \text { flood control basins } \\
+ \text { stretches of } \\
\text { widening }\end{array}$ \\
\hline Project costs in $\mathrm{CHF}$ & 28 Mio & 2.6 Mio & 30 Mio & 10-15 Mio & $15 \mathrm{Mio}$ \\
\hline
\end{tabular}

Source: interviews

above sea level now show an insufficient level of structural diversity (Arnold et al. 2009). Modifications of rivers lead to more intensive runoff peaks. In combination with heavy real estate development in flood plains in the last few decades, the potential for damage from flooding has dramatically increased since the late 1980s (Zaugg 2003). Additional impacts can be expected as a consequence of ongoing climate change. Already the occurrence of undesired effects have led to a change in the paradigm for river engineering since the early 1990s, and federal and cantonal policies and regulations now aim to provide more space for rivers, including intentional inundation of agricultural land (BUWAL/BWG 2003). The challenge for the implementation of this policy is that almost every patch of land in Switzerland is used for a particular purpose. Since the 1980s, collaborative and participative planning processes have been considered a way to reconcile increasingly competing interests in flood plains. In Switzerland, stakeholder participation in these settings occurred, in projects with sufficient size, by means of advisory groups that were created through invitation by the executive team. Formally, these advisory groups did not have any decision making power. Typically, members were representatives of cantonal offices from sectors such as conservation or fishery, representatives of NGOs, municipal representatives, and, sometimes, landowners. The meetings of advisory groups were held about four times a year with different frequency of meetings over the lifetime of a project depending on how the project had progressed.

\section{Methods}

To address the research questions, we chose five completed projects that combined flood control and restoration, and we conducted semistructured interviews with participants in the projects' advisory groups. To be included in the sample frame, the planning of a project had to have been completed at least three years prior to our study, the project had to be well documented, and the implementation of the project's plans had to have been completed. A further criterion for selecting a project was that it had to be in the German or RhaetoRomance speaking area of Switzerland on account of the language preferences of the investigators. 
Our initial search yielded 22 projects. From these, we selected projects with some level of public interest and those whose project leaders were willing to participate in the study. To qualify for the criterion of public interest, the case's planning process had to involve representatives from municipal agencies and from the fields of conservation, fisheries, and landowners. In addition, the restored river stretch had to be longer than $1 \mathrm{~km}$. Applying these criteria resulted in five river engineering projects along the Flaz, Kander, Langete, Thur, and Wyna streams. Table 1 briefly presents the characteristic features of these cases. All the projects we investigated were marked by the conflict between the traditional land users and the people trying to gain more space for the river, either to protect downstream infrastructure and buildings, or to provide more space for aquatic and riparian flora and fauna. The Langete case represented an early case of collaborative or integrated planning. Representatives from the sectors of drinking water, fishery, flood protection, and conservation were involved in the planning.

In a second sampling step, we selected the interviewees within the cases. We applied purposeful sampling to obtain interviewees who would be able to provide us with rich information from a wide range of perspectives (Patton 1990, Coyne 1997). We partly based this sampling on information provided to us by the project leaders. For each case, we selected five to six interviewees to represent the following functions: authority in charge of the planning process, conservation, i.e., governmental or civil society organizations, fishing, landowners, and municipalities. We preferred participants who were continuously involved in the planning process, if possible from the beginning.

The interviews were guided by a list of key questions and optional subquestions that allowed a deeper exploration of interesting issues. The questions addressed six features: the role of the interviewee in the planning process; characteristics of the process; context features; power of stakeholders to influence the process; effects of the collaborative planning process on the interviewee, on other participants in the planning group, and beyond the group; and the relationships among the participants and their changes over time.

Overall, 26 interviews were conducted. All but one of the interviewees was male, and the ages of most of the interviewees ranged from 45 to 65 . The gender distribution reflected that river restoration and flood prevention is a male dominated business in Switzerland. The woman interviewed was the only female involved in the five advisory groups. For more detailed information about the interviewees, see Table 2. The interviews were digitally recorded, transcribed, and coded. Two researchers developed the coding scheme through an iterative process after thoroughly reviewing a random sample of interviews. Once the coding scheme was developed, one researcher coded every paragraph of every interview. The
Table 2. Interviewee numbers indicating planning cases (first digit) and the interviewee within the case (second digit), interviewee functions, date, and length of interviews.

\begin{tabular}{|c|c|c|c|}
\hline & Function & Interview date & $\begin{array}{l}\text { Interview } \\
\text { length } \\
\text { (h:min) }\end{array}$ \\
\hline $1 \_1$ & Conservation NGO representative & 23.02 .2010 & $01: 15$ \\
\hline 1_2 & Farmer & 02.03 .2010 & 01:13 \\
\hline $1 \_5$ & Municipal council representative & 17.05.2010 & \\
\hline $1 \_3$ & $\begin{array}{l}\text { Chairman regional planning } \\
\text { association }\end{array}$ & 17.02 .2010 & $01: 27$ \\
\hline $1 \_4$ & $\begin{array}{l}\text { Project leader (planning and } \\
\text { construction agency [cantonal]) }\end{array}$ & 23.02 .2010 & $01: 12$ \\
\hline $2 \_1$ & $\begin{array}{l}\text { Governmental conservation } \\
\text { agency representative (cantonal) }\end{array}$ & 22.02 .2010 & $01: 20$ \\
\hline $2 \_2$ & $\begin{array}{l}\text { Secretary flood control } \\
\text { association (inter-municipal) }\end{array}$ & 07.04 .2010 & 01:19 \\
\hline $2 \_3$ & $\begin{array}{l}\text { Secretary regional planning } \\
\text { association }\end{array}$ & 19.02 .2010 & $01: 25$ \\
\hline $2 \_4$ & Fishery inspector (cantonal) & 22.02 .2010 & $01: 22$ \\
\hline $2 \_5$ & $\begin{array}{l}\text { Representative of the planning } \\
\text { and construction agency } \\
\text { responsible for river engineering } \\
\text { (cantonal) }\end{array}$ & 16.03 .2010 & 01:12 \\
\hline 3_1 & Conservation NGO representative & 08.04 .2010 & 01:06 \\
\hline $3 \_2$ & $\begin{array}{l}\text { Representative of the department } \\
\text { for construction and environment } \\
\text { (cantonal) }\end{array}$ & 13.04 .2010 & $00: 45$ \\
\hline 3_3 & $\begin{array}{l}\text { Agricultural department } \\
\text { representative (cantonal) }\end{array}$ & 28.04 .2010 & 00:55 \\
\hline 3_4 & $\begin{array}{l}\text { Representative of the department } \\
\text { for water-engineering ( cantonal) }\end{array}$ & 12.04 .2010 & \\
\hline 3_5 & Municipal council representative & 05.05 .2010 & 01:06 \\
\hline 4_1 & Municipal council representative & 01.03 .2010 & $00: 51$ \\
\hline $4 \_2$ & $\begin{array}{l}\text { Governmental conservation } \\
\text { agency representative (cantonal) }\end{array}$ & 08.03 .2010 & $01: 31$ \\
\hline $4 \_3$ & $\begin{array}{l}\text { Representative of local common } \\
\text { land collective }\end{array}$ & 01.03 .2010 & 01:10 \\
\hline 4_4 & $\begin{array}{l}\text { Project leader, governmental } \\
\text { fisheries agency representative } \\
\text { (cantonal) }\end{array}$ & 10.02 .2010 & $01: 58$ \\
\hline 4_5 & $\begin{array}{l}\text { Representative of local common } \\
\text { land collective }\end{array}$ & 22.02 .2010 & 01:46 \\
\hline $5 \_1$ & $\begin{array}{l}\text { Representative of tourism } \\
\text { commission }\end{array}$ & 23.03 .2010 & $00: 38$ \\
\hline $5 \_2$ & $\begin{array}{l}\text { Fisheries representative, } \\
\text { construction advisor }\end{array}$ & 25.03 .2010 & $00: 28$ \\
\hline $5 \_3$ & $\begin{array}{l}\text { President of the local land owner } \\
\text { cooperation }\end{array}$ & 04.05 .2010 & 01:15 \\
\hline 5_4 & $\begin{array}{l}\text { Council leader, member of } \\
\text { project team }\end{array}$ & 25.03.2010 & 01:05 \\
\hline 5_5 & $\begin{array}{l}\text { Responsible for ecological } \\
\text { monitoring (of water engineering } \\
\text { activities) }\end{array}$ & 26.03 .2010 & 01:06 \\
\hline 5_6 & Farmers' representative & 22.03 .2010 & $01: 30$ \\
\hline
\end{tabular}

second researcher coded a fraction of the interviews to enhance reliability of the coding. In our analysis, we followed discourse principles (Gee 2005, Waitt 2010) to find out which issues emerged around four topics: the question of learning, time requirements, most difficult issues to solve, and the effects of 
participation in general but particularly those extending into the community. Our approach was explorative and not a systematic comparison of the five cases. We focused on finding similarities and differences between the cases with an emphasis on finding evidence, or lack thereof, for the longterm effects of participatory planning processes described earlier in the literature. We were also interested in the forms in which these effects occurred.

\section{RESULTS}

We identified social and political capital building as well as ecological knowledge resulting from social learning as the main social effects. Regarding long-term or third-order effects, we detected few changes in norms or practices and only three new institutions. We present our results in detail, describe three different forms of social learning, and discuss conditions for the effects and costs of project realization. We also present results that either contradict or complement the social learning view on participatory planning.

\section{Social effects}

\section{Social learning}

We identified social learning on three levels: (1) social and political capital, (2) leading a participatory process, and (3) the benefits of providing more space for rivers.

(1) Interviewees reported a series of learning experiences that related to social and political capital or relational change. They said they had learned how to interact with other members of the planning group without causing disagreements. They learned that compromise helped more than stubbornly clinging to a previously held judgment. They learned to listen better to each other's concerns. The first quote by a conservationist exemplified that participants learned that stubbornness was not conducive when groups aimed to find a solution.

Well, we have certainly learned that we can achieve more when we do not stubbornly insist on something. (1_1)

A conservationist from another case, this time a cantonal representative, reported a fairly similar learning experience. In this quote learning to compromise was emphasized.

Forme personally, yes, that I am a little less stubborn with my requests. Well, I started with a fairly rigid attitude; I wanted to push through everything, $100 \%$ ... this is not possible; one has to compromise. (4_2)

The quote below illustrates how an interviewee had experienced the atmosphere among the members of the advisory group after they had overcome the early phase of conflict. The new atmosphere he described as follows, again emphasizing the key function of compromise.

I think it was really consensus; we had consensusoriented discussions; by all means in the sense of compromise [s]: 'you make a concession here, so we make a concession there. 'Maybe it was never openly expressed this way, but it was definitely thought. 'If you agree to the widening of the river then we will concur with the flood plain remaining at a higher level.' (3_1)

The same interviewee described earlier in the interview how he had changed his early, judgmental attitudes toward farmers.

I can also remember that all farmers were bad, and egoists and 'eco-preventers' [in my view] . . . and I have gained more sympathy for their point of view. And in certain points I have really changed my opinion. (3_1)

Overall, mainly those members representing conservation concerns reported increased understanding for the position of other participants, particularly farmers, as learning outcomes of their participation. Moreover, interviewees, who were in their early forties or younger at the time of the planning, tended to report learning experiences, whereas, older participants questioned the importance of learning or accorded this issue little importance, and rather emphasized the leadership style or techniques as central to the planning process.

Asked about the qualities a conservationist representing the canton should have, one interviewee, retired from such a position, responded from his long-term experience, not only drawing on this case but on his whole career:

Secondly, he should be [additional to having professional/specialist conservation knowledge] a team player. He should be able to listen before making his point. He should listen to the problems [others formulate], but also clearly state his concerns, not in an extreme way, but he should state what the law requires. ... When he encounters a nogo [in the position of other actors] then he has to provide leeway [to others]. . . . A certain flexibility is necessary without agreeing to lazy compromises. (2_1)

The concept of compromise featured in all five planning cases, where it had positive as well as negative connotations. Apart from the just mentioned 'lazy compromise' the 'healthy compromise' also appeared. The distinction between compromise (some lose, others win, but nobody loses in a way that would lead to strong opposition) and consensus (all agree, nobody loses) was often not made. The concept of consensus received more appreciation in the case of Thur, which had been initially full of conflict compared to the other cases.

(2) The second major learning experience we identified related to leading a participatory planning process. All the leaders we interviewed were leading the participatory or collaborative 
planning process for the first time. Leaders were aware that they were expected to do things differently than in the past, and give space to a variety of river-related concerns. Given that little formalized or easily accessible knowledge was available on how to lead a participatory planning process, those in charge were faced with a difficult task. We found leaders with little experience working toward a consensus in the early phases of planning. Over the course of the planning process, some learned that group members expected rather firm guidance and that finding solutions with acceptable losses for the stakeholders (compromise) was a more realistic aim than trying to make everybody content (consensus).

We found good leaders had a clear vision, were able and willing to listen, and did not try to make everybody happy. Inexperienced leaders tended to be too open to the preferences of participants, and, as a consequence, postponed decision making, which frustrated at least some participants because they sensed that the planning process was not progressing. Several participants explicitly expressed a wish for clear leadership and guidance. The following quote, in which a respondent, a conservationist, characterized two of the individuals from the canton who led the process in different phases, illustrated this perception of leadership. For him, good leadership style consisted of having a clear vision and working toward its realization. The conservationist appreciated this leadership style, even though the leader was less in favor of conservation than earlier leaders, because it helped to move the project forward.

[The forerunner of the last leader] was so indecisive, he was open to compromises, but he didn't have such a clear vision . . . and he didn't lead [the process] that well. And then later came Mr. Roth, he was pretty good; he pushed the whole thing forward. Well, he wasn't necessarily a conservationist, but he brought things together. One could work with him. (1_1)

One leader explicitly drew the personal conclusion that he would apply a firmer leadership style next time.

[I learned] regarding my role as project leader. Today I would lead more forcefully, in a more dominant manner. (4_4)

A further challenge was that stakeholders were hard to motivate to participate in such advisory groups, if they did not have some influence on decision making, which they formally did not have. They tended to drop out of the process or to participate as silent members. The related task for project leaders was to identify or even create issues on which the participants could meaningfully deliberate.

Also, you have to create bargaining chips or issues of value so stakeholders have something to negotiate. This can be something of intangible or material value. (4_4)
Interestingly, even individuals who were not in a leadership position reported having learned about leadership within these processes. A fisheries representative formulated it as follows.

\section{We learned from each other. I learned a lot from him [the project leader] on how to lead, for example. And I have also learned a lot from the conservationists about the trees, about their functions, and about this and that and the birds. That was give-and-take. (2_4)}

(3-a) The third type of social learning we identified related to ecology and ecological measures, that is, the acquisition of factual knowledge. A number of respondents reported that their attitudes toward river engineering, particularly its ecological or 'green' aspects, had changed in the planning process. This resulted, for example, from being exposed to other members of the group with good ecological knowledge.

I am [now] convinced that nature-oriented river engineering is the way to go ... The representative of the conservationists pointed out to us beetles and butterflies that we hadn't noticed before. And, you know, one suddenly said: yes, during maintenance we won't discharge [the gravel], we will store it on the shore then insects and creatures that don't have the opportunity to develop in other places can live here when this is all cleaned up. Such things; one started to see things; points and aspects emerged one had not thought of in the past. (2_2)

Over time, individuals with good ecological knowledge seemed to have received high recognition of their knowledge within the groups. And subsequently, the appreciation of these members and the measures they proposed were high (as long as they were open to compromises).

Well, the gentleman I mentioned earlier . . . he is a retired school teacher. . . he is such an expert [in ecological matters]... when he said something then we agreed to it ... he has such incredible expertise. (1_3)

Board members also reported that others 'became green,' that is, experienced a change in attitude toward the approval of nature-oriented flood prevention measures, as a result of being repeatedly exposed to a very convincing participant with nature-oriented/conservationist attitudes, expert knowledge, and good communication skills.

Learning about ecological river engineering was not only generated as a result of personal interaction with people with ecological expertise, but also through trial and error. The need for this trial and error process resulted from the fact that the paradigm shift toward more nature-oriented river engineering was not sufficient to form a new and more nature-oriented 
practice. This new practice had to be created in close collaboration with board members with different kinds of knowledge. However, the lack of knowledge also provided cause for quarrels between members when distrust still prevailed in the relationships. The following quotation exemplified this point:

In the first project we were all bloody greenhorns. I know I didn't have a clue about water engineering, zero . . . But that wasn't a surprise to me. However, it was a surprise to me that the water engineers were just as much novices as I was [regarding natureoriented measures of water engineering]. They couldn't say what the river would do if one did this or that to it, e.g., lower the flood plain. That was a huge topic and caused quarrelling again and again. Nobody knew what would happen. ... And then they tried many different things. . . . Yes, it was trial and error in my perception. (3_1)

It thus seemed necessary for a new understanding to be created that involved participants' recognizability of their own knowledge gaps and tolerance of the knowledge gaps of their counterparts, at least so they could agree on first measures as trial cases.

In a similar vein, it was also reported from three of the five cases, and that is all the cases that were planned in several stages, that the projects became 'greener' with each stage. This meant that measures became bolder over time as a consequence of good experiences with moderate natureoriented measures.

In the beginning we struggled with it, people were scared that the plants and the wood would be washed away and that one would have to start from the beginning. But after we had accomplished-in total we had 30 sections on 15 kilometers-after we had accomplished 10 sections and one could see the result; one could see how the plants were growing. ... how the plants were getting roots, then we said "this is the way to go." (2_2)

(3-b) An important result was that social learning related to nature-oriented river engineering also occurred through the public approval of corresponding measures. Interviewees from three different projects reported that planning group members were surprised when citizens started to use restored stretches of the rivers for recreational purposes. The planning groups interpreted these uses as public approval of the projects. This also contributed to bolder planning and measures in later phases of the projects.

Today the people take much pleasure in the flood absorption basins everywhere. They go for a run or take a walk. Our new problem now is to provide [enough] parking space for the people, so they [can] go with theirfamilies and their dogs. This has turned into a local recreation area. We did not anticipate this. (1_3)

Even a strong critic of one of the projects, a farmer who was heavily impacted by the project, admitted its recreational value.

This summer we had many people at this loop [of the river] they built over there. It was really nice, I have to say. We have also been over there a lot with the kids. The kids could bathe a bit. On a nice Sunday it was like being on the Riviera. (1_2)

Overall, planning group members, initially critical of the new paradigm of providing more space for rivers, accepted it in response to public approval of corresponding river engineering measures. Almost all those interviewees who did not represent conservation interests in one way or the other from the outset of the process reported that they were now convinced that 'going green' was the way to go.

Asked about the effects of participatory planning beyond the actual projects, a couple of interviewees spoke of their preparatory value for other independent projects nearby, i.e., in the same watershed. This was particularly true when the same individuals met in new contexts, as spelled out in the next quote.

When you have planned something similar earlier, you know the people; you can link the new project up to the old one. . . . Thus, you can link it to the success you had. . . . It is like having the field prepared. . . . You don't have to explain everything from the beginning. (4_4)

A project could also have had an impact when different individuals were involved by creating what a respondent called an imitation effect.

What we realize now is that people in Bever and LaPunt [2 and $6 \mathrm{~km}$ from the project side] want to continue [with their projects]. That means that an imitation effect exists. The [representatives of] municipalities say: when it turns out like this, we want to have something similar in our community. Hence, one might conclude that such projects might have it easier in the future. The more examples we have in certain places, the higher is their acceptance. (5_5)

Limitations and alternatives to social learning Another crucial finding was how clearly limitations to learning were stated. For example, interviewees noted that learning could not be expected in all regions or could only occur to a minimal extent in some areas. One project leader stated that 
restoration projects were only possible in certain subregions of his area of responsibility. He stated that in other subregions, the prevailing 'mentalities' would not allow the new paradigm to be followed.

Also, some leaders expressed a critical attitude toward the possibility of learning to lead. Asked about his learning experience, one of the leaders clearly expressed that he did not believe that leading such processes could be learned.

\section{I would say it is instinctive what one does [in those situations/processes]. I think one can't learn it. It depends on the person. (1_4)}

Asked whether he would do anything differently if he could do it again, he confirmed his cautious attitude toward learning and reflection.

\section{I have already conducted my self-criticism. And I have to say it went well. And in terms of improvement nothing caused me to say I would do it differently next time. I can't say that. (5_5)}

According to one interviewee, the leader of the Kander project had a broad education, was well connected locally, and a real go-getter. These types of qualities can complement the openness to learn. The next quote emphasized that particular individuals could make a large difference with regard to changes in practice. This referred particularly to the education of a person and implied that on the spot learning was not necessarily needed to achieve change.

It has to do a lot with [particular] people. Now the responsible person [for maintenance work] is $\mathrm{Mr}$. Luerm and I think he was trained as a lumberjack and I know him from a conservation NGO as an excursion guide. He is just 'greener'(eco-friendlier) than the one who did his job before. (1_1)

Trust, changes in relationships, and social effects with weak evidence

Overall, the issue of trust was mentioned less than we expected. Trust and its importance for reaching agreements was, however, emphasized as an outcome of participatory planning when conflict had occurred at an earlier phase of the process, as in the case of the Thur project. Contributions to trust building were reported as a result of repeated meetings, but most importantly by compliance with promises.

A frequently mentioned social effect of participation was simply getting to know people. Moreover, the positive impact of established relationships on the working capacity of a group was widely noted. In particular, governmental and municipal participants reported changes in relationships. The relationship building among cantonal members was, naturally, particularly high in the case of Langete, which focused on sectoral integration, and less on stakeholder participation, and which was also characterized by planning activities in the summer months and implementation in the wintertime for a couple of years, leading to a high number of meetings in different settings over time. Representatives of various municipalities, who usually did not interact even though they acted in spatial proximity, also got to know each other to some degree.

Another crucial finding was that there was no evidence of social effects of the participatory planning process extending into the community, defined as people in an area spatially proximate to the project. Asked about whether relational effects extended into the community, many respondents could not make much sense of the question. One interviewee, however, particularly emphasized the small spatial scope of communication and trust effects, stressing that only people who were directly involved in the planning process experienced such changes. This interviewee emphasized that one had to start with trust-building measures from the beginning in new locations, even those close by, when different stakeholders were involved.

Additionally, social effects did not seem to persist over time. One interviewee, who had reflected considerably on the planning process, said that he saw trust as something that was built up in such processes but that it eroded over time. He said that trust needed constant investment to be maintained. He also noted that trust could be resurrected, meaning that individuals interacted more easily the second time they worked together, even though the relationship cooled off in the interim. A further challenge to relational effects was that they disappeared when actors retired from their functions and new actors, e.g., municipal leaders, were elected. These constant losses of relationships meant that constant investments were necessary to maintain certain levels of trust in a local setting.

Regarding new institutions that were proposed as third-order effects, we identified two organizations that were created late in the processes, probably in the implementation phase or even after project implementation. One was an organization that brought conservationists and farmers together; the other one was a yearly symposium on water issues in the municipality that undertook the Flaz project. One institution was founded in an early phase of the Langete project and constituted the special purpose association the involved municipalities founded as the organizing body of this project.

\section{Conditions and costs}

\section{Conditions}

We could not identify specific process characteristics, such as the level of stakeholder influence or group size, that could be clearly attributed to particular social outcomes, e.g., trust building or social learning. We, however, found some indication that more intense stakeholder involvement yielded 
more relational effects. Also, respondents mentioned certain general factors as positive, without further specifying the particular contributions of these factors.

Information on projects directly from project leaders and not, for example, from newspapers was an important part of stakeholder satisfaction with the process. Stakeholders appreciated receiving explanations about the information that had been used to make decisions. Such information enabled stakeholders to backtrack the decision making process of the executive team. Participation in the implementation phase was emphasized as particularly positive. There were three likely reasons for the importance of participation in implementation. First, it seemed to be easier to agree on solutions in the field than on a map, probably because ideologies did not interfere as much when a concrete problem had to be solved. Second, in the field, information could be communicated much more efficiently than on paper. Participants could see things in the field and not have to read reports or try to figure out what was meant on plans or maps. Third, the more dynamic and informal setting of a construction site seemed to enable a more relaxed atmosphere than sitting around a table, and this more casual setting may also have fostered actors' willingness to endorse actions.

Numerous comments suggested that participants expected the process to have clear aims and functions, but that participants also wanted to have a say. One might anticipate tension between these two expectations. Our observation, however, was that participants could be satisfied by a relatively small 'objective' influence if the project leader clearly communicated which topics were subject to negotiation and which were not. This clarification prevented the group from discussing issues on which it had no influence, helped it to focus on topics it could affect, and thus reduced the likelihood that the members would perceive the participatory process as useless.

\section{Time requirements and emotional costs}

Costs included time investments and emotional expenditure, and they were both fairly high in all cases. The time that elapsed from problem identification to first implementations ranged from 11 to 13 years in all five cases. We suggest that these huge time requirements reflected the difficulty of participants to accept changes in paradigms and to their biophysical environments. These significant time investments also reflected the challenges of building a workable group that involved relationship building.

Several interviewees emphasized how challenging and laborious the interaction with stakeholders was.

And then you have to identify the individual stakeholders. Who are they, where are they, how are they concerned, what is their problem? And that is incredibly hard work, that is really a lot of incredibly hard work this individual attendance of the individually affected people. (3_3)

We called the associated costs emotional costs. Emotional costs can result from exposure to comments from angry interlocutors or even verbal abuse, which usually did not happen in group meetings but in bilateral conversations between farmers and cantonal representatives. Frequent changes in leadership may also have indicated high emotional costs. In one case, four different individuals led the process over its 11-year duration; in another case, the leader was replaced once. Despite these costs, however, going ahead with planning and implementing the ideas of the executive team without stakeholder approval was not considered a viable course of action in any of the cases. Potential legal battles were avoided by the project leader, as was open conflict, and numerous interviewees said it would not have been possible to realize the projects in a nonparticipatory way.

We could not identify trade-offs between activities that contributed to substantial outcomes and those that had social effects; rather, the latter were clearly reported to support the former. Participants saw the benefits of both a good atmosphere and good relationships to a functioning group, allowing it to make decisions and produce outputs. However, participants did not appreciate activities with a specific focus on the social dimension and relationship building, speaking disdainfully of 'debate clubs,' implying that the purpose of those meetings were debating itself and not trying to find a solution. Participants preferred to focus on technical solutions or other physical changes in the field. Consequently, participants expected meetings to move the planning process significantly toward these solutions. The disdain expressed by interviewees for relationship-building exercises suggested that project leaders might do well to design relationshipbuilding activities that participants do not view as such.

Assessing how much time was required to build trust within a group was difficult for the respondents. Asked about this issue, the interviewees gave fairly vague responses, but emphasized that it took some time until the group found itself, i.e., members got to know each other to a degree that made productive work possible. Two respondents reported that it took about two years to achieve this.

\section{DISCUSSION AND CONCLUSION}

We started with the following questions: (1) what was the contribution of participatory planning to the creation of social effects, (2) what conditions would foster these effects, and (3) what could participatory planning ultimately be expected to contribute to the transformation toward more adaptive socialecological systems.

We identified three main social learning effects: learning about the benefits of ecological measures, leading a participatory process, and interacting appropriately with others in decision 
making settings. Trust was mainly recognized as important when the process was initially conflictive. General relationship building was the most mentioned but the lowestlevel, positive effect, most notably among municipal and cantonal representatives. We found little indication of thirdorder effects.

Our results challenge earlier research because we found neither the trust nor the third-order effects to the extent described by Innes and Booher (1999). We saw some potential for combined flood prevention and restoration projects to launch similar projects in the same region or river system because of the preparatory and imitation value of realized projects. However, we suggest that the preparatory value affected the river engineering community rather than the region, and that the outcome of extension of effects into the community should be understood in this sense. Our results confirm recent findings suggesting that the social learning effects of participatory planning methods are smaller, in the field, than what is expected based on the theoretical considerations (Garmendia and Stagl 2010).

Regarding the second question, we could not identify particular links between project conditions and social effects. This might have been due to the low variability of the cases in terms of these conditions. This might also have reflected that project leaders tried to organize the planning processes in an adaptive way until they achieved agreements on plans and plan implementation, holding meetings when they sensed they were necessary, and inviting additional participants to the group when they identified further issues to be addressed by the advisory boards. Also the settings for all five cases were largely identical when it came to the political, historical, and economic environments. Despite this, every case was characterized by many dimensions, including biophysical ones, which we did not systematically consider. This makes it hard to generalize across cases about the causal links between conditions or inputs on the one hand and outcomes on the other. However, interviewees mentioned receiving firsthand information and being able to backtrack decision making as important aspects of the projects. We interpreted those characteristics as relevant process conditions for stakeholder satisfaction and assumed some link between stakeholder satisfaction and social effects. To empirically investigate this link, however, is a subject for future research. Participants also appreciated clarity in the process and clarity about the role of the process for higher level decision making. These are dimensions the process leader could influence. Therefore, we suggest that process leaders' activities have two major effects: first, they directly influenced process conditions and, second, they moderated between process conditions and outputs. That is, we speculate that leaders acted as moderating figures between conditions and outcomes, meaning that good leaders managed to achieve good outcomes even under unfavorable conditions. If leaders took this role, a clear relationship between conditions and outcomes would be hard to establish. Subsequently, research with the aim of establishing descriptions of objective process features and context conditions that enable particular outcomes do not seem overly promising. Inspired by the result of this study on the importance of building a workable group, we rather suggest that future researchers investigate to what degree knowledge of team building, as derived from organizational psychology, and valid for (permanent) organizations might apply to participatory planning settings. This new research could complement and refine findings on the crucial role of leadership noted by earlier studies (Carr et al. 1998, Olsson et al. 2004, Mostert et al. 2007).

Our practical recommendation is that leaders clearly communicate the role of different actors in the process at the outset, even though this risks some participants be disappointed. Additionally, leaders should provide participants with background information so they can trace back and understand why decisions have been made, and to create bargaining chips so participants have something on which they can actually decide. These might seem overly obvious recommendations to the majority of the readers from the scientific community. However, in practice project leaders have a tendency to hide the fact that stakeholders do not have any right to influence decision making. For some Swiss citizens, it is rather irritating not having the right to at least codecide. Thus it is a recurring challenge for leaders and participants to find their roles in participatory settings.

With regard to time requirements, our findings confirmed earlier research, specifically that it takes at least two years to build a workable group (Leach et al. 2002), although this timespan will surely depend on the intensity of participation. Work by Muro and Jeffrey (2012) complements our study regarding the frequency of meetings and suggests that strategic planning groups should meet at least six times a year. Regarding the relation between substantial project outcomes, e.g., implemented trial measures, and relational and cognitive changes, we provide further evidence on how the former contributes to the latter. However, these trial measures require time for planning, implementation, and evaluation, or for simply seeing whether measures worked in the intended way, contributing to long project times.

Regarding our third question on the contribution from participatory planning to social-ecological transformations, we suggest for the particular settings in our research that only moderate contributions should be expected from single participatory planning processes. The reasons for our suggestion are based on lower extent of learning than were hoped for in the social-ecological transformation community and very high costs of learning in terms of time, particularly when involved actors participated voluntarily and thus could only dedicate little time to a planning process. Additionally, 
competing worldviews regarding the value of learning, as well as little persistence of built trust, had an impact on a limited extension of learning and its effects. We suggest that the learning we identified is characterized by the acceptance of a new strategy in dealing with excess water (on the local level) that was promoted by higher level government entities (in this case, cantons). Only for some participants did learning entail questioning one's own mental model of rivers and how to deal with them. Factors noted by interviewees as hindering social learning included rural attitudes or stubbornness of mostly older and rural populations that insisted on controlling rivers. We also identified attitudes with an inherent focus on talent or instinct as the basis for action, paired with a limited willingness to self-reflect and criticize one's own actions as contradicting the learning paradigm.

The finding on limitations to learning supports earlier results suggesting that most learning achieved in participatory planning is only single-loop learning (Pahl-Wostl 2009), i.e., the acceptance of new ways of dealing with an issue instead of more fundamental changes in mental models. The reasons for low persistence and the limited extension of social effects, we suggest, are that trust effects only emerge among actors who directly communicate with each other and that trust vanishes over time if interactions are not maintained. This result, that the small spatial extension of social effects and the disappearance of trust, challenges expectations formulated by Innes and Booher (1999). The results, however, do support a study by Arnold et al. (2012) who emphasized that learning does not naturally result from bringing stakeholders together, that historic conceptualizations of the environment can dominate discussions of stakeholders, and that leaders play an important role in creating an environment that fosters productive engagement.

On a more progressive note, we suggest that a positive feedback loop or dynamic can emerge between actors that represent conservation concerns on the one hand, and conservation-critical actors on the other, when both are open to different kinds of learning. It seems particularly helpful when conservationists develop social and political capital, which has been called relational capital by Muro and Jeffrey (2012), and when conservation-critical members acquire ecological or cognitive knowledge related to the natural environment in a social learning process in these groups. Together these two kinds of social learning seem to enable agreements on plans and implementations, which might be rather cautious in the beginning but evolve to bolder measures over time. Project leaders can support this dynamic by communicating a clear vision, encouraging understanding among participants, being decisive, and sharing the background information and rationales for decisions.

The implications of the study are limited because we only considered successful participatory projects, i.e., those that resulted in an implemented project. We also only interviewed people who were involved in the process. We consequently lack outsider perspectives. A further limitation of the study is the lack of systematic consideration of technical and biophysical aspects of the projects and their qualitative dimensions. Even though the projects were well documented, due to time constraints, we could only skim the voluminous documentation in some cases. In other cases, this material had already been archived and we preferred to use the limited time of our interview partners to have conversations with them about the projects rather than asking them to pull out material. Whereas this material would have provided us with technical details, we did not expect it to inform us about the qualitative dimensions of the project, such as design features, leadership and facilitation style, or the transparency of the process. Further studies focusing on social learning only should certainly use already formulated expectations when developing research questions and designs to investigate social learning as already demonstrated by Muro and Jeffrey (2012). We, on the contrary, had a very broad starting point heavily relying on the framework by Innes and Booher (1999), which also allowed us to investigate which social effects did not emerge. This might not be considered useful information, but we considered it worthwhile to investigate and also to report that new institutions seldom emerged and other thirdorder effects were also rare.

One should be cautious in deriving broad conclusions about participatory planning processes and their contributions to social-ecological transformations from this study because our empirical evidence was limited to river engineering cases in a country with a particular democratic tradition and high levels of political autonomy at the municipal level. The waterengineering sector is heavily dominated by male individuals. Those in charge have been trained as engineers, which might have an impact on accepted fixed starting points in the search for a solution to a flood-risk problem. The educational background and gender mix might also influence how and to what extent social learning occurs. Despite its long democratic tradition, women's suffrage was only introduced at the federal level in 1971 in Switzerland, and women's involvement in political issues at the local level is still low. This implies that political activities might still follow male dominated rules. Thus, the results of this study need to be confirmed in other settings, before broader conclusions on the effect of participatory planning on social-ecological transitions can be drawn.

Regarding future research we have two suggestions. First, we suggest caution when focusing heavily on the concept of social learning, whose worth might be obvious among academics but can only be shared with a fraction of the practitioners. We think that the concepts researchers promote have to resonate with the aims of practitioners, because researchers and their topics might otherwise well be perceived as an obstacle. For 
example, to promote in-depth discussions and dialogue might serve the purpose of learning, but it might be perceived as utopian and impractical in the daily practice and time pressure of a project. Hence, future research could focus on the tradeoffs between long-term goals, such as social learning, and short-term goals, such as successfully finalizing concrete projects, and could investigate how more win-win opportunities could be realized.

Second, because we found that leaders were able to influence what can be called quality dimensions of participatory processes, such as the level of transparency, we suggest that future research specify the meaning of these rather abstract concepts for the concrete practice of participatory planning. Transparency and similar concepts are partly proposed in the literature for normative or theoretical reasons, but their meaning in concrete participatory settings is sometimes not entirely clear. However, when respondents state that they appreciate getting informed about how and why certain decisions have been made by the project leader, this can be seen as an operationalization of transparency. Hence, future research could further bridge the gap between theoretical criteria and their meaning in on-the-ground projects and by doing so contribute to the convergence of academic debate and the practice of participatory planning.

Despite our rather critical assessment, we found that participatory planning was judged by participants as the only way to realize the projects. Several interviewees said there was no alternative to planning that tried to include different actors' perspectives through communication and dialog. Thus, in the end, the question on whether the expected social effects emerge does not seem to be the decisive one, at least not for the members involved. Moreover, we found that it was difficult to launch the planning process in a case with some conflict and low levels of trust at the start. This confirms the notion that social capital is an input as well as an output factor of participatory planning (Sabatier et al. 2005). We suggest that successful participatory planning has significant potential to preserve or maintain social and political capital. As participatory planning also requires some level of social and political capital, it might function as a positive feedback process that maintains competences needed to confront future challenges.

Our results also indicate that participatory processes are highly time intensive and that they require patience. A participatory planning process depends on substantial input, such as extensive working hours from administrative personnel, engineering consultants, and voluntary participants. To achieve social and substantial effects from participatory planning, we thus suggest shifting resources from technical to communicative planning measures.
Responses to this article can be read online at: http://www.ecologyandsociety.org/issues/responses. $\mathrm{php} / 5154$

\section{Acknowledgments:}

We would like to thank Eva-Maria Nordström and two anonymous reviewers for helpful comments on a previous version of this article and acknowledge financial support by the Competence Center Environment and Sustainability (CCES) of the Swiss Federal Institute of Technology (ETH) Domain.

\section{LITERATURE CITED}

Armitage, D., M. Marschke, and R. Plummer. 2008. Adaptive co-management and the paradox of learning. Global Environmental Change-Human and Policy Dimensions 18:86-98. http://dx.doi.org/10.1016/j.gloenvcha.2007.07.002

Arnold, J. S., M. Koro-Ljungberg, and W.-L. Bartels. 2012. Power and conflict in adaptive management: analyzing the discourse of riparian management on public lands. Ecology and Society 17(1): 19. http://dx.doi.org/10.5751/ES-04636-170119

Arnold, M., B. Schwarzwälder, K. Beer-Tóth, M. Zbinden, and K. Baumgart. 2009. Mehrwert naturnaher wasserläufe. untersuchung zur zahlungsbereitschaft mit besonderer berücksichtigung der erschliessung für den langsamverkehr. Bundesamt für Umwelt (BAFU), Bern, Switzerland.

Birner, R., and H. Wittmer. 2003. Using social capital to create political capital: how do local communities gain political influence? A theoretical approach and empirical evidence from Thailand. Pages 291-334 in N. Dolšak and E. Ostrom, editors. The commons in the new millenium. MIT Press, Cambridge, Massachusetts, USA.

Bourdieu, P. 1986. The forms of capital. Pages 241-258 in J. Richardson. Handbook of theory and research for the sociology of education. Greenwood, Santa Barbara, California, USA.

Bullock, R., and K. Hanna. 2007. Community forestry: mitigating or creating conflict in British Columbia? Society \& Natural Resources 21:77-85. http://dx.doi.org/10.1080/08941920701561007

BUWAL/BWG. 2003. Leitbild fliessgewässer schweiz. Für eine nachhaltige gewässerpolitik. Bundesamt für Umwelt (BAFU), Bern, Switzerland.

Carr, D. S., S. W. Selin, and M. A. Schuett. 1998. Managing public forests: understanding the role of collaborative planning. Environmental Management 22:767-776. http://dx. doi.org/10.1007/s002679900146 
Coleman, J. S. 1988. Social capital in the creation of human capital. American Journal of Sociology 94:S95-S120. http:// dx.doi.org/10.1086/228943

Coyne, I. T. 1997. Sampling in qualitative research. Purposeful and theoretical sampling; merging or clear boundaries? Journal of Advanced Nursing 26:623-630. http:// dx.doi.org/10.1046/j.1365-2648.1997.t01-25-00999.x

Cundill, G., and C. Fabricius. 2010. Monitoring the governance dimension of natural resource co-management. Ecology and Society 15(1): 15. [online] URL: http://www. ecologyandsociety.org/vol15/iss1/art15/

Dorcey, A., and T. McDaniels. 2001. Great expectations, mixed results: trends in citizen involvement in Canadian environmental governance. Pages 247-302 in E. Parson, editor. Governing the environment: persistent challenges, uncertain innovations. University of Toronto Press, Toronto, Ontario, Canada.

Garmendia, E., and S. Stagl. 2010. Public participation for sustainability and social learning: concepts and lessons from three case studies in Europe. Ecological Economics 69:1712-1722. http://dx.doi.org/10.1016/j.ecolecon.2010.03.027

Gee, J. P. 2005. An introduction to discourse analysis: theory and method. Routledge, New York, New York, USA.

Höppner, C., J. Frick, and M. Buchecker. 2007. Assessing psycho-social effects of participatory landscape planning. Landscape and Urban Planning 83:196-207. http://dx.doi. org/10.1016/j.landurbplan.2007.04.005

Hostmann, M., and A. Knutti. 2009. Befreite wasser entdeckungsreise in revitalisierte flusslandschaften der schweiz. Rotpunktverlag, Zurich, Swizterland.

Innes, J. E., and D. E. Booher. 1999. Consensus building and complex adaptive systems - a framework for evaluating collaborative planning. Journal of the American Planning Association 65:412-423. http://dx.doi.org/10.1080/0194436$\underline{9908976071}$

Kuhlicke, C., A. Steinführer, C. Begg, C. Bianchizza, M. Bründl, M. Buchecker, B. De Marchi, M. Di Masso Tarditti, C. Höppner, B. Komac, L. Lemkow, J. Luther, S. McCarthy, L. Pellizzoni, O. Renn, A. Scolobig, M. Supramaniam, S. Tapsell, G. Wachinger, G. Walker, R. Whittle, M. Zorn, and H. Faulkner. 2011. Perspectives on social capacity building for natural hazards: outlining an emerging field of research and practice in Europe. Environmental Science \& Policy 14:804-814. http://dx.doi.org/10.1016/j.envsci.2011.05.001

Leach, W. D., N. W. Perkey, and P. A. Sabatier. 2002. Stakeholder partnerships as collaborative policymaking: evaluation criteria applied to watershed management in California and Washington. Journal of Policy Analysis and Management 21:645-670. http://dx.doi.org/10.1002/pam.10079
Leach, W. D., and P. A. Sabatier. 2005. Are trust and social capital the keys to success? Watershed partnerships in California and Washington. Pages 233-257 in P. A. Sabatier, W. Focht, M. Lubell, Z. Trachtenberg, A. Vedlitz, and M. Matlock, editors. Swimming upstream : collaborative approaches to watershed management. MIT Press, Cambridge, Massachusetts, USA.

Mostert, E., M. Craps, and C. Pahl-Wostl. 2008. Social learning: the key to integrated water resources management? Water International 33:293-304. http://dx.doi. org/10.1080/02508060802275757

Mostert, E., C. Pahl-Wostl, Y. Rees, B. Searle, D. Tàbara, and J. Tippett. 2007. Social learning in European river-basin management: barriers and fostering mechanisms from 10 river basins. Ecology and Society 12(1):16. [online] URL: http:// www.ecologyandsociety.org/vol12/iss1/art19/.

Muro, M., and P. Jeffrey. 2008. A critical review of the theory and application of social learning in participatory natural resource management processes. Journal of Environmental Planning and Management 51:325-344. http://dx.doi. org/10.1080/09640560801977190

Muro, M., and P. Jeffrey. 2012. Time to talk? How the structure of dialog processes shapes stakeholder learning in participatory water resources management. Ecology and Society 17(1): 3. http://dx.doi.org/10.5751/ES-04476-170103

Newig, J., and O. Fritsch. 2009. Environmental governance: participatory, multi-level - and effective? Environmental Policy and Governance 19:197-214. http://dx.doi.org/10.1002/ eet.509

Olsson, P., C. Folke, and F. Berkes. 2004. Adaptive comanagement for building resilience in social-ecological systems. Environmental Management 34:75-90. http://dx.doi. org/10.1007/s00267-003-0101-7

Pahl-Wostl, C. 2009. A conceptual framework for analysing adaptive capacity and multi-level learning processes in resource governance regimes. Global Environmental Change 19:354-365. http://dx.doi.org/10.1016/j.gloenvcha.2009.06.001

Pahl-Wostl, C., J. Sendzimir, P. Jeffrey, J. Aerts, G. Berkamp, and K. Cross. 2007. Managing change toward adaptive water management through social learning. Ecology and Society 12 (2): 30. [online] URL: http://www.ecologyandsociety.org/ vol12/iss $2 /$ art30/.

Patton, M. Q. 1990. Qualitative evaluation and research methods. Second edition. Sage, Newbury Park, California, USA.

Rauschmayer F., J. Paavola, and H. Wittmer. 2009. European governance of natural resources and participation in a multilevel context: an editorial. Environmental Policy and Governance 19:141-147. http://dx.doi.org/10.1002/eet.504 
Reed, M. S. 2008. Stakeholder participation for environmental management: a literature review. Biological Conservation 141:2417-2431. http://dx.doi.org/10.1016/j.biocon.2008.07.014

Rodela, R., G. Cundill, and A. E. J. Wals. 2012. An analysis of the methodological underpinnings of social learning research in natural resource management. Ecological Economics 77:16-26. http://dx.doi.org/10.1016/j.

ecolecon.2012.02.032

Sabatier, P. A., W. Focht, M. Lubell, Z. Trachtenberg, A. Vedlitz, and M. Matlock, editors. 2005. Swimming upstream : collaborative approaches to watershed management. MIT Press, Cambridge, Massachusetts, USA.

Sheppard, S. R. J., and M. Meitner. 2005. Using multi-criteria analysis and visualisation for sustainable forest management planning with stakeholder groups. Forest Ecology and Management 207:171-187. http://dx.doi.org/10.1016/j. foreco.2004.10.032

Stringer, L. C., A. J. Dougill, E. Fraser, K. Hubacek, C. Prell, and M. S. Reed. 2006. Unpacking "participation" in the adaptive management of social ecological systems: a critical review. Ecology and Society 11(2): 39. [online] URL: http:// www.ecologyandsociety.org/vol11/iss2/art39/.

Wagner, C. L., and M. E. Fernandez-Gimenez. 2008. Does community-based collaborative resource management increase social capital? Society \& Natural Resources 21:324-344. http://dx.doi.org/10.1080/08941920701864344

Wagner, C. L., and M. E. Fernandez-Gimenez. 2009. Effects of community-based collaborative group characteristics on social capital. Environmental Management 44:632-645. http:// dx.doi.org/10.1007/s00267-009-9347-z

Waitt, G. 2010. Doing Foucauldian discourse analysis revealing social identities. Pages 217-240 in I. Hay, editor. Qualitative methods in human geography. Oxford University Press, Oxford, UK.

Zaugg, M. 2003. Mehr raum den fliesharpgewässern: more space for the rivers - the path to a sustainable flood prevention. GAIA - Ecological Perspectives for Science and Society 12:201-207. 